https://doi.org/10.52058/2786-4952-2021-4(4)-365-375

Литвиненко Олена Олександрівна кандидат психологічних наук, доцент кафедри практичної психології Інституту людини, Київський університет імені Бориса Грінченка, бул. І. Шамо 18/2, м. Київ, 02154, тел.: (044) 294-00-25, e-mail: o.lytvynenko@kubg.edu.ua, https://orcid.org/0000-0003-2152-7285

\title{
СПЕЦИФІКА КОГНІТИВНОЇ СФЕРИ ПІДЛІТКІВ У КОНТЕКСТІ ЇХ ОСОБИСТІСНОГО СТАНОВЛЕННЯ
}

Анотація. У статті представлено результати дослідження особливостей та специфіки когнітивної сфери особистості підлітків, в межах якого було проаналізовано окремі когнітивні прояви підлітків, визначено характер та інтенсивність взаємозв'язків між представленими змінними, систематизовано виявлені статистичні закономірності та на їх основі здійснено теоретичні узагальнення, щодо специфіки когнітивних проявів підлітків в контексті їх особистісного становлення. Наведено отримані емпіричні дані, що доводять наявність безпосередніх двосторонніх взаємозв'язків між окремими проявами когнітивної сфери в контексті особистісного становлення підлітків. При цьому характер зв'язку (прямий, або обернений) також залишається сталим. Це дозволяє говорити про інтрадетермінованість когнітивних компонентів, а, відповідно і про їх компенсаторність. Доведено взаємну обумовленість окремих складових когнітивної сфери особистості підлітків. Визначено та описано систему взаємозалежностей між когнітивними спрямованостями та дисфункційними когнітивними схемами підлітків. Доведено, що розуміння типових схем дозволяє передбачити прояв кожної зі спрямованостей. Натомість, аналіз когнітивних спрямованостей дозволяе передбачити прояв 11 з 18 дисфункційних схем. При цьому 7 схем залишаються не включеними у зазначену систему взаємозалежностей, тобто їх прояв не залежить від домінування в особи певної спрямованості. Виявлені взаємозв'язки мають значення як для психологічної діагностики, так і для психопрактичної діяльності, оскільки, 3 одного боку, дозволяють передбачити певні особливості когнітивної сфери на основі наявності інших їх проявів, а 3 іншого - забезпечують можливості використання компенсаторних механізмів у межах психологічної профілактики та корекції. Стаття може представляти інтерес для фахівців у сфері психології розвитку, практичних психологів та психотерапевтів, педагогів та усіх фахівців, сфера практичної діяльності яких передбачає активну взаємодію з підлітками.

Ключові слова: особистість, підлітковий вік, когніції, когнітивні спрямованості, дисфункційніi схеми. 
Журнал«Герспектвиитаіноовації наукиљ

(Серія«Гедагогіка», Серія«Гцихологія», Серія«Медицинв»

№4(4) 2021

Lytvynenko Olena Oleksandrivna Ph.D. in Psychology, Associate Professor of the Chair of Practical Psychology Borys Grinchenko University of Kyiv, Kyiv, 02154, tel.: (044) 294-00-25, e-mail: o.lytvynenko@kubg.edu.ua, https://orcid.org/ 00000003-2152-7285

\title{
SPECIFICS OF ADOLESCENTS' BEHAVIORAL MANIFESTATIONS IN THE CONTEXT OF THEIR PERSONAL FORMATION
}

\begin{abstract}
The article presents the results of a study of peculiarities and specifics of the cognitive sphere of adolescents' personality. With this aim there were analysed individual cognitive manifestation of adolescents, determined the nature and intensity of relationships between the presented variables, systematized statistical regularities and on their basis there were made theoretical generalizations about the specificity of cognitive manifestations of adolescents in the context of their personal formation. The obtained empirical data are presented, proving the existence of direct bilateral relationships between individual manifestations of the cognitive sphere in the context of adolescents' personal formation. At the same time, the nature of the connections (direct or reverse) also remains constant. This allows to talk about the intradetermination of cognitive components, and, accordingly, about their compensatory nature. There was proved the mutual conditionality of separate components of cognitive sphere of personality of teenagers. There was defined and described the system of interdependencies between cognitive orientations and maladaptive cognitive schemas of adolescents. It was also proved that the understanding of typical schemas allows to predict the manifestation of each of the orientations. Instead, the analysis of cognitive orientations allows us to predict the manifestation of 11 of the 18 maladaptive schemas. Thus 7 schemas remain not included in the specified system of interdependencies, so their display does not depend on dominance of a certain orientation. The identified relationships are important for both psychological diagnosis and psycho-practical activities, because, on the one hand, they allow to predict certain features of cognitive sphere based on the presence of other manifestations, and on the other - to provide opportunities to use compensatory mechanisms in psychological prevention and correction. The article may be interesting for specialists working in the field of age psychology, practical psychologists and psychotherapists, teachers and all practitioners whose profession provides active interaction with adolescents.
\end{abstract}

Keywords: personality, adolescence, cognitions, cognitive orientations, dysfunctional schemes.

Постановка проблеми. Згідно класичної когнітивної моделі у психології, емоції і поведінка індивіда залежать від сприйняття ним різних життєвих 
обставин. При цьому вважається, що почуття людини визначаються не об'єктивними подіями, а способом, у який вона їх тлумачать [1]. Тобто емоції $\epsilon$ похідними від когніцій та виникають як результат когнітивної інтерпретації та реструктуризації отриманого досвіду. Набуття цього досвіду починається 3 дитинства, коли в індивіда формуються певні переконання про самого себе, оточуючих і світ вцілому, але найбільш інтенсивним стає на етапі підлітковості. Таким чином, особливої актуальності набуває наукове вивчення проблеми становлення когнітивної сфери особистості підлітків.

Аналіз наукових досліджень і публікацій. Основні, або глибинні когнітивні переконання особистості - це настанови, які є фундаментальними, всеосяжними, та, переважно, неусвідомлюваними i непридатними для вербалізації. Носій таких ідей розцінює їх як об'єктивну інформацію про навколишній світ. Глибинні переконання розглядаються переважно в межах когнітивної психології та психотерапії, де вони визначаються як настанови фундаментального рівня, котрі є всеосяжними, укоріненими і такими, що погано піддаються змінам, а також сягають високої міри узагальнення. На основі глибинних формуються проміжні переконання (які також часто не піддаються чіткому вираженню словами), що включають ставлення, правила і припущення. Своєю чергою, проміжні переконання породжують автоматичні думки, тобто вербальні формулювання найбільш поверхневого рівня пізнавальної діяльності [2]. Таким чином, когнітивна організація особистості являє собою ієрархію більш або менш стійких уявлень про світ та способів тлумачення подій, що відбуваються. Формування глибинних переконань безпосередньо пов'язане 3 особистою генезою, оскільки характер та специфіка переконань індивіда залежить від умов, в яких відбувається його становлення, водночас, сформовані переконання визначають спрямованість цього становлення.

Важливою характеристикою переконань, при цьому, $є$ їх ієрархічність. Психологи-когнітивісти зазначають, що переконання індивіда мають рівневу структуру. Так, розвиваючи ідеї Д. Вестбрука та співавторів, Р. Мак Маллен у своїй теорії виокремлює поверхневі переконання, більш глибинні переконання i центральні (базові) переконання. Поверхневі переконання - це ті думки, які індивід легко усвідомлює і відкриває іншим. Базові (центральні) переконання індивід не може виявити без спеціальних зусиль. Це не означає, однак, що вони в принципі не усвідомлюються. На думку автора, за допомогою терапевтичної роботи або спеціальних розпитувань базові переконання можна розкрити [3]. Відповідно, досліджуючи специфіку формування когнітивних утворень індивіда на різних етапах його становлення, необхідно аналізувати особливості прояву переконань різного рівня.

3 іншого боку, відповідно до теорії А. Бека та співавторів, обробка людиною 
Журнал«Герспектвиитаіноовації наукиљ

(Серія«Гедагогіка», Серія «Гиихологія», Серія «Медицинв»

№4(4) 2021

інформації 3 навколишнього світу заснована на базових переконаннях, впроваджених в схеми. При цьому, порушення нормального функціонування індивіда зазвичай бувають пов'язані з його «когнітивною вразливістю». Кожна людина характеризується унікальною вразливістю і чутливістю відповідно до наявних у неї схем [4].

Поняття «схеми» у когнітивних теоріях особистості використовується для позначення відносно стійких когнітивних моделей, за допомогою яких людина сортує і синтезує інформацію, що надходить до неї з зовнішнього світу. Але, при цьому, схеми розглядаються не тільки як когнітивні структури, але i як когнітивно-афективні комплекси, що формуються в процесі набуття досвіду [5]. Відповідно, саме схеми спрямовують індивіда, визначають ефективність закріплення у нього тих чи інших поведінкових патернів та типових способів емоційного реагування на події. Когнітивні схеми певною мірою «пояснюють» суть подій, що відбувається 3 індивідом. На основі цих пояснень формується реакція на події, а сукупність таких реакції утворює характерні для особи поведінкові патерни.

Дж. Йонг і співавтори визначили 18 схем, які об’єднуються у п’ять більш узагальнених груп. Зазначені групи схем є наступними: 1) схеми втрати зв'язку та відкинення (покинення, недовіри, емоційної депривації, дефективності, соціальної ізоляції); 2) схеми обмеженої автономії і здатності досягати успіху (залежності, очікування на катастрофу, злиття, некомпетентності); 3) схеми порушення меж (особливого статусу, недостатнього самоконтролю); 4) схеми спрямованості на інших (підкорення, самопожертви, пошуку визнання) і 5) схеми надмірної пильності та інгібіції (негативізму, емоційної інгібіції, надвисоких стандартів, покарання) [6]. Ці визначення дисфункційних схем були сформовані переважно в результаті клінічних спостережень в межах когнітивної психотерапії, а не внаслідок емпіричних досліджень. 3 іншого боку, емпіричні дослідження підтверджують факт їх існування [7].

Таким чином, метою нашої статті стало наукове дослідження окремих особливостей когнітивної сфери підлітків та аналіз системи взаємозв'язків між ними.

Виклад основного матеріалу. Основними елементами когнітивної сфери підлітків ми вважаємо їх глибинні переконання та когнітивну спрямованість. Глибинні переконання, або схеми, не відображаючись на рівні свідомості, формують ставлення особи до інших людей та ситуацій, а також інтерпретацію подій навколишнього світу. Своєю чергою, когнітивна спрямованість відображає змістову наповненість когніцій індивіда, а також задає умовний вектор його темпоральної орієнтації на минуле або майбутнє. 3 нашої точки зору, така орієнтація не лише визначає розвиток прогностичної функції психіки особи, але i є безпосередньо пов'язаною з ї психоемоційним станом, сприйманням себе та інших, а також рівнем розвитку навичок коупінг-поведінки. Основними 
методами вивчення когнітивної сфери підлітків в межах даного дослідження стали Дюссельдорфський опитувальник схем для дітей [8] та контент-аналіз персональних наративів. Для визначення взаємозв'язку між змінними використовувався двосторонній множинний регресійний аналіз, результати якого наведено у таблицях 1-2.

Як видно 3 таблиці 1, когнітивна спрямованість на позитивні емоції $\epsilon$ характерною для підлітків, яким властиві когнітивні схеми емоційної депривації та очікування на катастрофу. В першому випадку така закономірність пояснюється активацією механізмів гіперкомпенсації, коли особа, стикаючись 3 недостатністю теплих емоційних взаємин, фіксує увагу на питаннях емоційної взаємодії та обмірковуванні можливості вираження позитивних емоцій. Зазначимо, що традиційно схема емоційної депривації вважається такою, що призводить до ігнорування питань емоційності як таких, що не мають зв'язку 3 особистим досвідом (Арнц, 2020). Отримані ж нами результати доводять, що ці питання можуть не лише витіснятись, але й викликати підвищену увагу суб'єкта.

Таблиия 1

Взасмозв'язок когнітивної спрямованості з дисфункійними схемами

\begin{tabular}{|c|c|c|c|c|c|}
\hline \multirow[t]{2}{*}{ Модель } & \multicolumn{2}{|c|}{$\begin{array}{c}\text { Нестандартизовані } \\
\text { коефіціснти }\end{array}$} & \multirow{2}{*}{$\begin{array}{c}\text { Стандартизовані } \\
\text { коефіціснти } \\
\text { Бета }\end{array}$} & \multirow[t]{2}{*}{$\mathbf{t}$} & \multirow{2}{*}{$\begin{array}{l}\text { Значи } \\
\text {-мість } \\
\end{array}$} \\
\hline & $\mathrm{B}$ & SD & & & \\
\hline \multicolumn{6}{|c|}{ Когнітивна спрямованість на емоції (+) } \\
\hline (Константа) & $-0,340$ & 0,109 & & $-3,120$ & 0,002 \\
\hline Емоц. депривація & 0,43 & 0,14 & 0,151 & 3,090 & 0,002 \\
\hline $\begin{array}{c}\text { Очік. на } \\
\text { катастрофу }\end{array}$ & 0,31 & 0,13 & 0,118 & 2,412 & 0,016 \\
\hline \multicolumn{6}{|c|}{ Когнітивна спрямованість на емоцї (-) } \\
\hline (Константа) & 0,546 & 0,119 & & 4,596 & 0,000 \\
\hline Самопожертва & 0,035 & 0,015 & 0,109 & 2,373 & 0,018 \\
\hline $\begin{array}{c}\text { Очікування на } \\
\text { катастрофу }\end{array}$ & 0,024 & 0,010 & 0,108 & 2,336 & 0,020 \\
\hline \multicolumn{6}{|c|}{ Когнітивна спрямованість на соціальну взаємодію (+) } \\
\hline (Константа) & $-0,235$ & 0,100 & & $-2,338$ & 0,020 \\
\hline Самопожертва & 0,054 & 0,014 & 0,173 & 3,777 & 0,000 \\
\hline \multicolumn{6}{|c|}{ Когнітивна спрямованість на соціальну взаємодію (-) } \\
\hline (Константа) & 0,162 & 0,074 & & 2,204 & 0,028 \\
\hline Дефективність & 0,039 & 0,010 & 0,187 & 4,053 & 0,000 \\
\hline Залежність & 0,029 & 0,010 & 0,138 & 2,995 & 0,003 \\
\hline Покинутість & 0,018 & 0,009 & 0,096 & 2,056 & 0,040 \\
\hline
\end{tabular}


Журнал«Герстективита інновації наукиљ

(Серія«Гедагогіка», Серія«ГЕихологія», Серія«Медицина»

№4(4) 2021

Продовження таблицчі 1

\begin{tabular}{|c|c|c|c|c|c|}
\hline \multicolumn{7}{|c|}{ Когнітивна спрямованість на абстрактні роздуми (+) } \\
\hline (Константа) & 0,054 & 0,065 & 0,830 & 0,047 \\
\hline Емоційна інгібіція & 0,027 & 0,010 & 0,127 & 2,746 & 0,006 \\
\hline Залежність & 0,020 & 0,010 & 0,092 & 1,994 & 0,047 \\
\hline \multicolumn{7}{|c|}{ Когнітивна спрямованість на абстрактні роздуми (-) } \\
\hline (Константа) & 0,164 & 0,050 & 3,316 & 0,001 \\
\hline Негативізм & 0,018 & 0,008 & 0,100 & 2,155 & 0,032 \\
\hline \multicolumn{7}{|c|}{ Когнітивна спря.мованість на майбутне } \\
\hline (Константа) & 0,255 & 0,061 & 4,143 & 0,000 \\
\hline Покинутість & $-0,020$ & 0,009 & $-0,101$ & $-2,188$ & 0,029 \\
\hline \multicolumn{7}{|c|}{ Когнітивна спрямованість на минуле } \\
\hline (Константа) & $-0,022$ & 0,049 & $-0,450$ & 0,047 \\
\hline $\begin{array}{c}\text { Очік. на } \\
\text { катастрофу }\end{array}$ & 0,016 & 0,08 & 0,092 & 1,996 & 0,047 \\
\hline
\end{tabular}

Натомість, спрямованість на позитивні емоції обумовлюється схемою очікування на катастрофу, що пояснюється, передусім, механізмами витіснення. В цьому випадку підлітки, стикаючись 3 надмірною тривогою через невизначеність майбутнього та не маючи достатніх навичок для ії толерування, намагаються витіснити зазначені переживання, фокусуючись та тому, що для них є зрозумілим та передбачуваним, а саме - на емоціях. Зазначимо, що дана схема детермінує також прояв когнітивної спрямованість на негативні емоції. Тобто важливим $є$ сам факт фіксації на емоціях, незалежно від їх модальності.

Спрямованість на негативні емоції також властива особам, які мають підвищені показники за схемою самопожертви. Тобто, будучи схильними поступатись власними інтересами, цінностями та переконаннями заради інших, такі підлітки переживають суттєвий дискомфорт, який, окрім емоційної сфери, виражається також в типових для них когніціях.

Ще однією когнітивною спрямованістю, яку детермінує схема самопожертви, $є$ позитивна спрямованість на соціальну взаємодію.

Очевидно, що соціальна відкритість та готовність до компромісів, притаманна особам 3 домінуючою схемою самопожертви, обумовлює легкість у встановленні та підтримці приязних взаємин 3 оточенням, що і знаходить відображення у їх провідних когніціях.

3 іншого боку, негативний аспект спрямованості на соціальну взаємодію характерний для підлітків 3 переважанням схем дефективності, залежності та покинутості. Зазначимо, що дві з цих схем відносяться до групи втрати зв'язку та відкидання, що в повній мірі пояснює детермінацію ними орієнтації індивіда на аналіз труднощів у взаєминах з оточенням та на неможливість встановити 3 ними довірчі стосунки. Своєю чергою, схема залежності визначає надмірну фіксацію на міжособистісних стосунках, результатом якої є втрата власної ідентичності та 
переживання пов'язаного з цим дискомфорту.

Обумовленість прояву когнітивної спрямованості на абстрактні роздуми схемами залежності та емоційної інгібіції пояснюється двома факторами. 3 одного боку, підліткам зі схемою залежності властиве прагнення справляти позитивне враження на оточення, що дозволяє їм бути приналежним до певної спільноти. У якості однієї зі стратегій формування такого враження виступає демонстративний оптимізм, а відповідно, і орієнтація на позитивні роздуми. 3 іншого боку, для підтримання заданого рівня оптимізму необхідним стає стримування (інгібіція) власних емоцій та переживань, особливо тих, що мають негативний характер.

Передбачуваним $є$ взаємозв'язок негативних абстрактних роздумів зі схемою негативізму, оскільки саме ця схема обумовлює песимістичне сприйняття особою навколишнього світу та свого місця в ньому, а також появу окремих депресивних тенденцій. Все це, стаючи егосинтонним для особистості, визначає іiї схильність зосереджувати увагу на роздумах, пов'язаних 3 пошуком та відтворенням катастрофічних сценаріїв різного плану.

Достатньо обгрунтованим $\epsilon$ також обернений взаємозв'язок когнітивної орієнтації на майбутнє зі схемою покинутості. Дана схема вважається такою, що детермінує появу в особи переконання, що вона не здатна будувати міцні гармонійні стосунки 3 оточенням та $є$ приреченою на самотність. Саме тому схема покинутості виключає можливість орієнтації на майбутнє та виступає в якості заперечення реалій повсякденного життя.

Протилежна представленій вище когнітивній орієнтації спрямованість на минуле пов'язана зі схемою очікування на катастрофу. Пояснення такого зв'язку полягає в тому, що дана схема активує почуття тривоги щодо майбутнього та можливих перспективних небезпек. Тому набагато більш безпечною для суб'єкта виявляється орієнтація на минуле та багаторазова румінація щодо подій, які вже відбулись.

Проаналізувавши таким чином обумовленість прояву когнітивних спрямованостей дисфункційними схемами, можемо звернутись до протилежних взаємозв'язків, а саме до аналізу умов, за яких можливою стає поява тих чи інших когнітивних схем. Результати регресійного аналізу свідчать, що прояв 50\% схем (9 з 18) обумовлюється властивою індивіду спрямованістю. Розглянемо більш детально кожну з них.

Схема недовіри обумовлюється орієнтацією на негативну соціальну взаємодію, а також на майбутнє. Тобто негативний, травматичний досвід інтерперсональної взаємодії стає чинником, що формує когнітивну спрямованість, відображається в особистих наративах суб' єкта, а також визначає прояв у нього відповідної схеми. При цьому особи, які схильні проявляти надмірну підозрілість та недовірливість стосовно інших, значну увагу приділяють роздумам про майбутнє, плануванню своєї активності та пошуку способів убезпечити себе від імовірних потенційних небезпек. 
Журнал «ерстективита інновації науки»

(Серія «Гедагогіка», Серія «Тихологія», Серія«Медицина»

№4(4) 2021

Відповідна орієнтація на негативну соціальну взаємодію, 3 огляду на негативний коефіцієнт Бета, мінімізує вірогідність прояву схеми дефективності. Водночас, протилежна зазначеній, орієнтація на позитивну взаємодію підвищує ймовірність прояву даної схеми. Тобто домінування в індивіда глибинних переконань про власну неповноцінність грунтується на прагненні до активної міжсуб'єктної інтеракції та отримання специфічних вигод від даного процесу.

Крім того, передумовою прояву схеми дефективності $\epsilon$ орієнтація на позитивні емоції.

Таблиия 2

\section{Взаємозв'язок дисфункійних схем з когнітивною спрямованістю}

\begin{tabular}{|c|c|c|c|c|c|}
\hline Модель & B & SD & Бета & $\mathbf{t}$ & Знач. \\
\hline \multicolumn{6}{|c|}{ Недовіра } \\
\hline (Константа) & 6,4441 & 0,070 & & 92,268 & 0,000 \\
\hline Соц. взаємодія (-) & $-0,581$ & 0,213 & $-0,126$ & $-2,729$ & 0,007 \\
\hline Майбутнє & $-0,448$ & 0,203 & $-0,102$ & 2,201 & 0,028 \\
\hline \multicolumn{6}{|c|}{ Дефективність } \\
\hline (Константа) & 5,870 & 0,073 & & 80,936 & 0,000 \\
\hline Соц. взаємодія (-) & $-0,790$ & 0,221 & $-0,164$ & $-3,571$ & 0,000 \\
\hline Емоції (+) & 0,576 & 0,170 & 0,161 & 3,381 & 0,004 \\
\hline Соц. взаємодія (+) & 0,455 & 0,204 & 0,105 & 2,233 & 0,026 \\
\hline \multicolumn{6}{|c|}{ Залежність } \\
\hline (Константа) & 5,870 & 0,073 & & 80,254 & 0,000 \\
\hline Соц. взаємодія (-) & 0,515 & 0,223 & 0,107 & 2,311 & 0,021 \\
\hline Минуле & 0,595 & 0,265 & 0,104 & 2,244 & 0,025 \\
\hline Емоції (-) & 0,399 & 0,194 & 0,096 & 2,052 & 0,041 \\
\hline Емоції (+) & 0,390 & 0,177 & 0,109 & 2,211 & 0,028 \\
\hline \multicolumn{6}{|c|}{ Некомпетентність } \\
\hline (Константа) & 5,592 & 0,080 & & 70,087 & 0,000 \\
\hline Емоції $(+)$ & 0,427 & 0,168 & 0,117 & 2,546 & 0,011 \\
\hline \multicolumn{6}{|c|}{ Особливий статус } \\
\hline (Константа) & 6,053 & 0,071 & & 85,165 & 0,000 \\
\hline Соц. взаємодія (-) & $-0,433$ & 0,217 & $-0,092$ & $-1,998$ & 0,046 \\
\hline \multicolumn{6}{|c|}{ Емоційна депривація } \\
\hline (Константа) & 5,358 & 0,075 & & 71,096 & 0,000 \\
\hline Емоції $(+)$ & 0,642 & 0,159 & 0,185 & 4,046 & 0,000 \\
\hline Роздуми (+) & 0,443 & 0,207 & 0,099 & 2,137 & 0,033 \\
\hline \multicolumn{6}{|c|}{ Покинутість } \\
\hline (Константа) & 6,059 & 0,081 & & 74,563 & 0,000 \\
\hline Майбутне & $-0,487$ & 0,234 & $-0,096$ & $-2,081$ & 0,038 \\
\hline
\end{tabular}


Продовження таблиці 2

\begin{tabular}{|c|c|c|c|c|c|}
\hline \multicolumn{7}{|c|}{ Самопожертва } \\
\hline (Константа) & 6,890 & 0,055 & & 125,16 & 0,000 \\
\hline Соц. взаємодія (+) & 0,556 & 0,147 & 0,173 & 3,777 & 0,000 \\
\hline \multicolumn{7}{|c|}{ Емоційна інгібіція } \\
\hline (Константа) & 6,455 & 0,076 & & 85,304 & 0,000 \\
\hline Роздуми (+) & 0,599 & 0,218 & 0,127 & 2,746 & 0,006 \\
\hline
\end{tabular}

Така тенденція цілком узгоджується 3 окресленою вище тенденцією: прагнення отримувати винятково позитивний емоційний та соціальний досвід призводить до психологічного травмування, що, своєю чергою, обумовлює формування специфічного уявлення про себе та заснованої на цьому уявленні схеми дефективності.

Схема залежності проявляється у випадку високої вираженості когнітивної орієнтації на минуле, негативну соціальну взаємодію та емоції (як позитивні, так i негативні). Зазначимо, що зв'язок з орієнтацією на соціальну взаємодію $\epsilon$ двостороннім, тобто не лише когнітивна спрямованість обумовлює прояв схеми, a i навпаки - схема визначає формування відповідної спрямованості. Логіка їх поєднання пояснена вище. Обумовленість схеми залежності орієнтацією на емоції пов'язана 3 загальною емоційністю осіб, яким вона притаманна та властивою їм тенденцією до раціоналізації та вербалізації власних афективних якостей. Орієнтація на минуле в даному випадку виступає в якості захисту від непередбачуваного майбутнього та можливості дистанціюватись від перспективних труднощів в інтерперсональній взаємодії.

Схема некомпетентності обумовлюється когнітивною орієнтацією на позитивні емоції. Тут, як і в попередніх випадках, взаємозв'язок базується на механізмах витіснення, що дозволяють індивіду уникати переживання щодо власних недоліків завдяки концентрації на позитивних аспектах емоційної сфери.

Прояв когнітивної схеми особливого статусу виключає наявність орієнтації на негативних аспектах соціальної взаємодії (від’ємний коефіцієнт Бета). Тобто підлітки, впевнені у своїй винятковості, не схильні критично оцінювати свою комунікацію з іншими, а натомість ідеалізують іiі, будучи переконаними в тому, що справляють винятково позитивне враження на оточення.

Вартим уваги є взаємозв'язок схеми емоційної депривації з орієнтацією на позитивні емоції. Логіка цього зв'язку полягає в тому, що, не будучи схильним до переживання і прояву сильних почуттів, суб'єкт, якому притаманна така схема, може приділяти значну увагу осмисленню своїх емоцій та спробам їх раціоналізувати. Водночас, зв'язок зазначеної схеми з орієнтацією на позитивні абстрактні роздуми є логічним та передбачуваним, оскільки дозволяє особі перейти від афективної спрямованості до власне когнітивної, яка $є$ для неї більш зрозумілою та комфортною.

Емпіричні дані свідчать, що можливість прояву схеми покинутості $\epsilon$ 
виключеною в осіб з когнітивною спрямованістю на майбутне. Таким чином, переживаючи через перспективні невдачі у стосунках 3 навколишніми, підлітки 3 такою схемою воліють уникати роздумів про майбутнє, побудови планів та висловлення фантазій 3 цього приводу. Також достатньо послідовним i обгрунтованим є взаємозв'язок між схемою самопожертви та спрямованістю на позитивну соціальну взаємодію. В даному випадку готовність жертвувати своїми інтересами заради інших дозволяє особі вибудовувати приязні стосунки 3 оточенням, які, своєю чергою, забезпечують позитивне сприймання нею міжособистісних інтеракцій.

Остання дисфункційна схема, що детермінується когнітивними орієнтаціями - це схема емоційної інгібіції. Її прояв пов’язаний зі спрямованістю на позитивні абстрактні роздуми. Тобто, придушуючи свої емоційні прояви та уникаючи їх відкритої демонстрації, такі підлітки надають перевагу розмірковуванню та схильні ділитися 3 оточенням власними ідеями та переконаннями, а не емоційними станами.

Узагальнюючи систему взаємозв'язків між компонентами когнітивної сфери особистості підлітків, можемо зробити декілька висновків.

Висновки. Виявлені взаємозв'язки мають значення як для психологічної діагностики, так і для психопрактичної діяльності, оскільки, 3 одного боку, дозволяють передбачити певні особливості когнітивної сфери на основі наявності інших їі проявів, а 3 іншого - забезпечують можливості використання компенсаторних механізмів у межах психологічної профілактики та корекції.

По-перше, існують стійкі зв’язки (як одно-, так і двосторонні) між когнітивними спрямованостями та дисфункційними когнітивними схемами.

По-друге, розуміння типових для підлітка схем дозволяє передбачити прояв у нього кожної зі спрямованостей.

По-третє аналіз типових для підлітка когнітивних спрямованостей дозволяє передбачити прояв окремих дисфункційних схем. При цьому 7 схем залишаються не включеними у зазначену систему взаємозалежностей, тобто їх прояв не залежить від домінування в особи певної спрямованості. До них належать схеми: недостатнього самоконтролю, підкорення, соціальної ізоляції, надвисоких стандартів, пошуку визнання, очікування на покарання та злиття.

Перспективи подальших досліджень у цій сфері полягають у практикоорієнтованому дослідженні способів і стратегій цілеспрямованого психологічного впливу на когніітивну сферу підлітків 3 метою гармонізації процесу їх особистісного становлення.

\section{Jimepamypa:}

1. Ellis A. Rational Emotive Behaviour Therapy: It Works for Me - It Can Work for You / A. Ellis. — New York : Prometheus Books, 2009. — 425 p.

2. Westbrook D. An Introduction to Cognitive Behavioural Therapy/ D. Westbrook, H. Kennerley, J. Kirk. — London : Sage Publications, 2007. — 345 p. 
3. McMullin R. The New Handbook of Cognitive Therapy Techniques / R. McMullin. New York : Norton Professional Books, 2009. — 375 p.

4. Beck, A. Cognitive Therapy of Personality Disorders (3rd ed.) / A. Beck, D. Davis, A. Freeman. - New York : The Guilford Press, 2014. - 392 p.

5. Beck A. Depression: Causes and Treatment/ A. Beck. - 2nd ed. - Pennsylvania : University of Pennsylvania Press, 2009. - 432 p.

6. Young J. Schema Therapy / J. Young, J. Klosko, M. Weishaar. — New York : Guilford Press, 2003. - $436 \mathrm{p}$.

7. Арнц А. Схема-терапія: модель роботи 3 частками / А. Арнц. - Львів : Галицька видавнича спілка, 2020. - 264 с.

8. Литвиненко О. О. Адаптація україномовної версії Дюссельдорфського опитувальника схем для дітей / О. О. Литвиненко // Науковий вісник Херсонського державного університету. Серія «Психологічні науки». - №3. - 2020. - С. 108-114.

\section{References:}

1. Ellis, A. (2009). Rational Emotive Behaviour Therapy: It Works for Me - It Can Work for You. Prometheus Books.

2. Westbrook, D., Kennerley, H., \& Kirk, J. (2007). An Introduction to Cognitive Behavioural Therapy. Sage Publications.

3. McMullin, R. (2009). The New Handbook of Cognitive Therapy Techniques. Norton Professional Books.

4. Beck, A., Davis, D., \& Freeman, A. (2014). Cognitive Therapy of Personality Disorders (3rd ed.). New York: The Guilford Press.

5. Beck, A. (2009). Depression: Causes and Treatment (2-ге вид.). University of Pennsylvania Press.

6. Young, J., Klosko, J., \& Weishaar, M. (2003). Schema Therapy. Guilford Press.

7. Arnts, A. (2020). Skhema-terapiya: model' roboty z chastkamy [Scheme-therapy: model of work with particles]. L'viv: Halyts'ka vydavnycha spilka [in Ukrainian].

8. Lytvynenko, O. (2020). Adaptatsiya ukrayinomovnoyi versiyi Dyussel'dorfs'koho opytuval'nyka skhem dlya ditey [Adaptation of the Ukrainian version of the Dusseldorf Schema Questionnaire for Children]. Naukovyy visnyk Khersons'koho derzhavnoho universytetu. Seriya «Psykholohichni nauky» - Scientific Bulletin of Kherson State University. Series: Psychological Sciences, №3, 108-114 [in Ukrainian]. 